\title{
Islamic Banking System as an effective element of Economy
}

\author{
Salam Al-Augby* \\ Sebastian Majewski** \\ Kesra Nermend ${ }^{* * *}$ \\ Agnieszka Majewska****
}

\begin{abstract}
The main goal of this paper is to present what the Islamic banks (the type of banks governs by Islamic law that governs every aspect of Muslims' life "Shariah") instruments are and why it is so important for the community. According to Shariah the payment or acceptance of interest charges (Riba) is prohibited in Islamic banking transactions. This paper is tried to describe the main features of the Islamic banking transactions and to identify the differences between Islamic and conventional banks. Also, this paper presents a survey of the historical evolution of the Islamic banking system in Muslim countries, starting with the first Islamic bank, early in the 1960's, Nasser Bank in Egypt. In conclusion, the Islamic banking system is a rapid growth one and the switch to Islamic banking will be a difficult task. Due to the fact, that in the last decade, the Islamic banking made its presence in all over the world markets not just in Islamic countries.
\end{abstract}

Keywords: Islamic Banking, Islamic Finance, Riba, Islamic Instruments

\section{Introduction}

The emergence of Islamic banking has been driven by the increasing number of Muslims who wish to lead their lives according to the Shariah, the legal code of Islam (Abdul-Majid, Saal, \& Battisti, 2010). The existence of Islamic banks in the second half of the 20th Century came as an offshoot of the newly rediscovered Islamic economics (Kahf, 2002). The Islamic banking is a financial industry with a very high growth rate, nowadays. It is a relatively young, the first bank, functioning on the base of the Shariah Law, was founded in 1963 in Egypt - the "MitGhamr Savings Bank", renamed afterwards in "Nasser Social Bank", but the first Islamic banks were the "Dubai Islamique banque" or "Dubai Islamic Bank", "Kuwait Finance House" and "Bahrain Islamic Bank" (Sadoveanu, 2011). The establishment of these banks paved the way for the creation of other Islamic financial institutions all over the world (Malaysia, 1999). Some form of Islamic financial services is now available in at least 70 countries (Husain, 2005).

\footnotetext{
${ }^{*}$ Ph.D Salam Al-Augby, University of Kufa, Student at Szczecin University, e-mail: salam.alabugby@yahoo.com

*** dr hab. Sebastian Majewski, Szczecin University, e-mail: sebastian.majewski@wneiz.pl

*** prof. inż. dr hab. Kesra Nermend, Szczecin University, e-mail: kesra@wneiz.pl

***** Ph.D Agnieszka Majewska, Szczecin University, e-mail: magnes@wneiz.pl
} 
The salient features of Islamic banking are the prohibition of interest payment in transactions, and the prohibition of undertaking or financing anti-social and unethical behaviour such as gambling, pornography and alcohol (Abdul-Majid, Saal, \& Battisti, 2010).

\section{Islamic Banking}

The Islamic Banking System is a progressive and pioneering financing system, working effectively in modern days in many parts of the world. In many developed and developing nations this unique financing system works side by side with other conventional banks in both market and non-market economy (Alam, 2003).

Islamic banking refers to a system of banking, which is Shariah (Islamic Law) complaint, and guided by Islamic economics (Baber, 2013) or it could be defined as the banking system which is in consonance with the spirit, ethos and value system of Islam and governed by the principles laid down by Sharia (Ahmad \& Shabbir, 2003).

Islamic banking is also known as an interest free banking system, as the Shariah disallows the acceptance of "Riba" (Botiș, 2013).

Islamic banking, the more general term, is based not only to avoid interest-based transactions prohibited in Islamic Shariah but also to avoid unethical and un-social practices. In practical sense, Islamic Banking is the transformation of conventional money lending into transactions based on tangible assets and real services. The model of Islamic banking system leads towards the achievement of a system which helps achieve economic prosperity (Ahmad \& Shabbir, 2003).

Lexically the word "Riba" means excess, increase or addition (Elasrag, 2014) meaning of interest, also known as "usury" (Botiș, 2013). Idiomatically (according to Islamic Interpretation) implies any excess compensation without due consideration (consideration does not include time value of money). This definition of Riba is derived from the Quran and is unanimously accepted by all Islamic scholars (Ahmad \& Shabbir, 2003).

The term Riba is used in the Shariah in two senses. The first is Riba An-Nasiyah (Riba in loans, interest charged on money loans), and the second is Riba-Al-Fadl (Riba in excess, interest which is charged in barter transactions of commodities).

Riba-Al-Fadl involves an exchange of unequal qualities or quantities of the same commodity simultaneously, and could therefore be described as the usury of surplus. Riba An-Nasiyah, the usury of waiting, involves the non-simultaneous exchange of equal qualities and quantities of the same commodity and does not therefore involve a surplus but only a difference in the exchange timing.

Some writers employ the term Riba An-Nasiyah to define such an exchange (El Diwany, 2010), according to islamic rule says "Every loan that derives a benefit (to the lender) is Riba" if Mr. A lends $100 \$$ to Mr. B (a borrower) with a condition that Mr. B shall return him $110 \$$ after one month. In this case, the extra amount of $10 \$$ is Riba or Interest (Ahmad \& Shabbir, 2003). 
Riba-Al-Fadl is excess compensation without any form of consideration in return (Elasrag, 2014).According to Abu Said al Khudri (May Allah be pleased with him) who narrated that Holy Prophet (Allah blessing and peace be upon him and his descendent) said:

"Gold for gold, silver for silver, wheat for wheat, barley for barley, dates for dates and salt for salt, like for like, payment made hand by hand. If anyone gives more or asks for more, he has dealt in Riba. The receiver and giver are equally guilty" it may be noted that economically speaking it would be irrational to exchange one kilogram of wheat with one and a half kilogram of wheat in a spot exchange. Therefore, some fuqaha have pointed out that Riba-al-Fadl has been prohibited because if it was left un-prohibited it could be used as a subterfuge for getting Riba-al-Nasiyah (Ahmad \& Shabbir, 2003).

\section{Islamic Prohibitions on Interest}

In Islam, there is no separation between mosque and state. Similarly, business cannot be separated from the Islamic religion. The Shariah (Islamic law) governs every aspect of a Muslim's religious practices, everyday life, and economic activities (Chong \& Liu, 2009). Shariah is the Islamic law came from various sources: The Quran: The Holy Book for Muslims, the Sunnah: (Prophet Mohammed's Sayings) the practice of Prophet Muhammad that he taught and practically instituted as a teacher of the Sharia and the best exemplar, Ijtihad: Personal reasoning of the Muslim jurists, Ijma: Views collectively agreed by Muslim scholars, Qiyas: Analogy (Kamali, 2003).

There are many psychological factors and virtuous factors (socially, economically and politically) behind the prohibition of Riba (Al-Sader, 1994); therefore, the Quran warns that such wealth mobilization engenders social imbalances (Gambling \& Karim, 1991). "Allah Almighty permits trading and forbids usury. Allah Almighty will deprive usury (Riba) of all blessings but (He) will give increase for deeds of charity... ' (Quran (Al-Baqara)2:275-276). Hazrat Al-imam Jaffer Al-Sadiq (peace be upon him) had been asked by one of his followers (What is the purpose of Riba banned) and he had answered. "If Riba was halal, the people would quit trades and what they need, thus Allah forbidding Riba to flee from the haram (forbidden) to halal (allowed), to trades (selling and buying), and the others remains as a loan" (Al-Sader, 1994).

There is no doubt that providing humanitarian and social services to the local community increases the bond between the bank and its local environment. This has a positive effect on the volume of deposits and other banking transactions. We should however note that banks are like other institutions in any society. They are made up of a group of individuals dealing with people in a particular social environment. There is no way that this group will not be influenced by its social environment or affected by the ideas, concepts and events that emerge in that environment. This is why banks participate in many charitable works and set programs of participation in charitable and social work, regardless of, and indeed above the demands of the principle of profit maximization. Banks contribute to public charitable 
works and set aside funds in their annual budgets for such purposes (Kahf, Success Factors of Islamic Banks, 2004, January).

The evidences that prove the revelation for Riba for Muslims are many one of these revelations for Riba is mentioned in [Surah An-Nisaa 4-161] "And because of their charging Riba while they were prohibited from it.", third Revelation: Riba/Interest has been abolished in the third verse of Surah Ali-e-Imran. The prohibition of Riba is laid down in the following words:

"O those who believe do not eat up Riba doubled and redoubled." [Surah Al-e-Imran 3-130].

The other revelation is Riba has categorically been prohibited in all its forms. The following set of verses is found in the Surah Al-Baqarah, verse 275-281 in the following words:

"Those who take interest will not stand but as stands whom the demon has driven crazy by his touch. That is because they have said: 'Trading is but like Riba'. And Allah has permitted trading and prohibited Riba. So, whoever receives an advice from his Lord and stops, he is allowed what has passed, and his matter is up to Allah. And the ones who revert back, those are the people of Fire. There they remain forever. Allah destroys Riba and nourishes charities. And Allah does not like any sinful disbeliever. Surely those who believe and do good deeds, establish Salah and pay Zakah, have their reward with their Lord, and there is no fear for them, nor shall they grieve. O those who believe fear Allah and give up what still remains of the Riba if you are believers. But if you do not, then listen to the declaration of war from Allah and His Messenger. And if you repent, yours is your principal. Neither you wrong, nor be wronged. And if there be one in misery, then deferment till ease. And that you leave it as alms is far better for you, if you really know. And be fearful of a day when you shall be returned to Allah, then everybody shall be paid, in full, what he has earned. And they shall not be wronged." [Surah Al-Baqarah 2:275-281]

The Prophet also taught his followers that poverty in their communities should not be tolerated (Choudhury, 1986), "He who takes interest and he who pays it and the scribe who writes the contract of usury and he who witnesses it - upon all will be the wrath of Allah Almighty (Hadith Muslim).

According to Islamic jurists and scholars (fuqaha), there are around 40 different Ahadith (sayings of the Prophet (Allah blessing and peace be upon him and his descendants')) on the subject of Riba and its prohibition from Holy Prophet (Allah's blessing and peace be upon him and his descendants').

Few of these are as follows:

1. From Hazrat Jabir (May Allah be pleased with him): The Prophet (Allah blessing and peace be upon him and his descendent), cursed the receiver and the payer of interest, the one who records it and the two witnesses to the transaction and said: "They are all alike [in guilt]."

2. Jabir ibn Abdallah (May Allah be pleased with him), giving a report on the Prophets Farewell Pilgrimage, said: The Prophet (Allah blessing and peace be upon him and his descendent) addressed the people and said "All of the Riba of Jahiliyyah is annulled. The first Riba that I annul is our Riba, that accruing to Abbas ibn Abd al-Muttalib (the Prophet's uncle); it is being cancelled completely." 
"All of the Riba of Jahiliyyah is annulled. The first Riba that I annul is our Riba, that accruing to Abbas ibn Abd al-Muttalib (the Prophet's uncle); it is being cancelled completely." (Ahmad \& Shabbir, 2003).

The Prophet descent Hazrat Al-imam Mohammed Bin Ali Al-baqir (peace be upon him) had said: "But Allah Almighty has forbidden Riba so as not to end righteousness" (Al-Sader, 1994).

Not only the Muslims consider the Riba is illegal according to Shariah but other believers have a signs in their Holy Books about usury the following references against the prohibition of Riba/usury are drawn from the old testament of the Bible:

1. Deuteronomy 23:19: "Thou shall not lend upon usury to thy brother; usury of money, usury of victuals, usury of anything that is lent upon usury."

2. Psalms 15:1, 2, 5: "Lord, who shall abide in thy tabernacle? Who shall dwell in thy holy hill? He that walketh uprightly, and worketh righteousness and speaketh the truth in his heart. He that putteth not out of his money to usury, nor taketh reward against the innocent."

3. Proverbs 28:8: "He that by usury and unjust gain increaseth his substance, he shall gather it for him that will pity the poor."

4. Nehemiah 5:7: "Then I consulted with myself, and I rebuked the nobles, and rules and said unto them, Ye exact usury, every one of his brother. And I set a great assembly against them."

5. Ezekiel 22:12: "In thee have they taken gifts to shed blood; thou hast taken usury and increase, and though hast greedily gained of thy neighbors by extortion, and hast forgotten me, said the Lord God." (Ahmad \& Shabbir, 2003)

Profit Loss Sharing (PLS) is the primary concept that Islamic finance is built and marketed upon (Dar \& Presely, 2000), because Islam defines 'interest' as a fixed or variable increase (and not decrease) on the principal amount, borrowed or loaned, for a fixed period of time. For example, if a lender loans $\mathrm{X}$ amount to a borrower at $\mathrm{Y} \%$ (no matter how small or large $\mathrm{Y}$ is) increase per annum, then $\mathrm{Y}$ is the interest, Riba, or usury. The lender and the borrower can be individuals, banks, financial institutions, governments, companies, or simply groups of people. The Islamic definition implies that in an interest-based transaction the lender has zero risk of losing money and a $100 \%$ probability of making extra money. The borrower on the other hand has $100 \%$ probability of paying extra money over and above the principal amount (Muzaffar, Gerard, \& AI-Elaiwi, 2000). Table (1) shows a comparison between Conventional Banks and Islamic Banks.

According to Shariah Muslims are not allowed to invest in businesses considered non-halal or prohibited by Islam, such as the sale of alcohol, pork, and tobacco; gambling; and prostitution (Chong \& Liu, 2009). As a result of complying with Islamic Shariah principles, Islamic banks should not deal in prohibited products and commodities such as pork and gambling (Ahmad \& Hassan, 2007). 
Table 1.

A comparison between Conventional Banks and Islamic Banks

\begin{tabular}{|c|c|c|}
\hline $\begin{array}{l}\text { Difference } \\
\text { No. }\end{array}$ & Conventional banking & Islamic banking \\
\hline 1 & $\begin{array}{l}\text { Money is a commodity besides medium of } \\
\text { exchange and store of value. Therefore, it } \\
\text { can be sold at a price higher than its face } \\
\text { value and it can also be rented out. }\end{array}$ & $\begin{array}{l}\text { Money is not a commodity though it is used } \\
\text { as a medium of exchange and store of value. } \\
\text { Therefore, it cannot be sold at a price higher than } \\
\text { its face value or rented out. }\end{array}$ \\
\hline 2 & $\begin{array}{l}\text { Time value is the basis for charging interest } \\
\text { on capital. }\end{array}$ & $\begin{array}{l}\text { Profit on trade of goods or charging on providing } \\
\text { service is the basis for earning profit. }\end{array}$ \\
\hline 3 & $\begin{array}{l}\text { Interest is charged even in case the } \\
\text { organization suffers losses by using bank's } \\
\text { funds. Therefore, it is not based on profit } \\
\text { and loss sharing. }\end{array}$ & $\begin{array}{l}\text { Islamic bank operates on the basis of profit and } \\
\text { loss sharing. In case, the businessman has suffered } \\
\text { losses, the bank will share these losses based on the } \\
\text { mode of finance used (Mudarabah, Musharakah). }\end{array}$ \\
\hline 4 & $\begin{array}{l}\text { While disbursing cash finance, running } \\
\text { finance or working capital finance, no } \\
\text { agreement for exchange of goods \& services } \\
\text { is made. }\end{array}$ & $\begin{array}{l}\text { The execution of agreements for the exchange of } \\
\text { goods \& services is a must, while disbursing funds } \\
\text { under Murabaha, Salam \& Istisna contracts. }\end{array}$ \\
\hline 5 & $\begin{array}{l}\text { Conventional banks use money as } \\
\text { a commodity which leads to inflation. }\end{array}$ & $\begin{array}{l}\text { Islamic banking tends to create link with the real } \\
\text { sectors of the economic system by using trade } \\
\text { related activities. Since, the money is linked with } \\
\text { the real assets therefore it contributes directly in the } \\
\text { economic development. }\end{array}$ \\
\hline 6 & Conventional Bank focuses on lending & Islamic Bank focuses on investment \\
\hline 7 & Apply only financial criteria & Apply moral criteria in investment \\
\hline
\end{tabular}

Source: Baber, H. (2013). Islamic Banking in Indian Economy-An Empirical Approach of Future Crisis. International Monthly Refereed Journal of Research In Management \& Technology Volume II., 34-47 and Ahmad, I., \& Shabbir, G. (2008). Frequently Asked Questions on Islamic Banking. Karachi: Islamic Banking Department State Bank of Pakistan.

\section{Islamic Finance}

Today, the Muslims constitute approximately 20 to $25 \%$ of the world population and continue to grow at a rapid pace. Muslims live in all corners of the world including the U.S., Europe, Russia, Africa, Asia, and the Far East. The U.S. alone has more than 6 million Muslims and their population continues to grow. A significant number of nations around the world today prefer to call themselves Islamic because of Muslim majorities (Muzaffar, Gerard, \& AI-Elaiwi, 2000).

Religion, if free from fundamentalism and corruption, can contribute much to reclaiming the enlightenment from the onslaught of new forms of repression represented in corporate practices backed by the State (Hind, 2007). Indeed, religious beliefs held by many, including many politicians and scientists, have not prevented their contribution to enlightenment (Hind, 2007). Religious teachings (in Judaism, Christianity, Islam or other Eastern religions or 
philosophies) that generally stand against social injustice and tyranny can contribute to and join the critical school agenda to defend and foster humanity and society against corporate greed and governmental systems supporting them (Wilson \& Hind, Economics, ethics and religion,The threat to reason: how the enlightenment was hijacked and how we can reclaim it, 1997, 2007).

The growth of Islamic banking both in Muslim and non-Muslim countries in recent years is remarkable (Wilson, Islamic investment in the UK., 2007) and Islamic finance, especially banking, has today become one of the fastest growing financial sectors globally (Rad, June 2006). Nowadays there exist more than 300 Islamic banks over the world. The main centers of Islamic banks, are still, mainly situated in the Middle East and Gulf region: Iran, Kuwait, Malaysia, Saudi Arabia and the United Arab Emirates. The total amount of assets, controlled by these banks is considered to be about $200-500 \mathrm{mld}$. \$, with a growth rate of $10-15 \%$ per year, according to the statistics provided on the web-site of the Financial Services Authority of United Kingdom (Sadoveanu, 2011).

Islamic banks in Islamic countries: In Iran, Pakistan, and Sudan, only Islamic banking is allowed. In other countries, such as Bangladesh, Egypt, Indonesia, Jordan and Malaysia, Islamic banking co-exists with conventional banking (Chong \& Liu, 2009).

According to statistics recently presented in the conference of Islamic banks that was held in Damascus this year, the manager of the Jordanian Islamic Arab Bank explained that the number of Islamic finance institutions has reached 390 all over the world in 75 countries with assets estimated by 500 to 1000 Billion dollars, and with development rate between $15 \%$ to $20 \%$ annually. This development in quantum of Islamic banking was not expected (Baber, 2013).

Several major Western banks, e.g., Citibank, ABN Amro, Bank of America, HSBC, Standard Chartered, and the Union Bank of Switzerland, either have Islamic Banking subsidiaries or offer Islamic financial products to their customers. Clearly Islamic Banking and Finance (IBF) has transformed itself from an obscure financial experiment to a major factor in global finance (Khan, 2010).

\section{Basic Guidelines of Islamic Banking}

From a more practical perspective defines Islamic Banking and Finance (IBF) as a system that adheres to the following principles: practices backed by the State.

1. Risk-sharing: the terms of financial transactions need to reflect a symmetrical risk/ return distribution among each participant to the transaction (Khan, 2010),

2. Materiality: all financial transaction must have "material finality," i.e., be directly linked to a real underlying economic transaction; thus options and most other derivatives are banned (Khan, 2010),

3. No exploitation: neither party to the transaction should be exploited (Khan, 2010),

4. No financing of sinful activities: transaction cannot be used to produce goods banned by the Quran (e.g., alcohol, pork products, gambling, pornography, etc.) (Khan, 2010). 
5. Uncertainty about the terms of contract (Gharar) - that Sharia law requires a complete transparency of the contract terms. Any uncertainty about price, delivery issues and other terms are prohibited (Chong \& Liu, 2009).

6. Speculative transactions (Maisir) - according to the Sharia Law, the investments in speculative transactions, such as derivatives, are considered to be illegal (Sadoveanu, 2011);

7. No violation: The bank does not violate Sharia in all of his transactions (Sadoveanu, 2011).

\section{Islamic Instruments}

For understanding the strategic trends of Islamic banking and finance, it is important to look at its roots in the recent history; all of it is recent anyway. Writings on Islamic economics describe the Islamic economic system as a market system that abides by the Islamic legal code, the Shariah (Kahf, 2002). The most dominant financing techniques promoted by Islamic banks as specifically Islamic are Mudarabah, Musharakah, Murabaha and Qardul Hassana (Kamla, 2009).

The modes of finance can be divided into three modes: Participatory Modes of Finance, Non Participatory modes of Finance (Khan, 2010) and Sub Contracts.

1. Participatory Modes of Finance: Main forms of participatory (profit and loss sharing) Islamic finance is:

a) Mudarabah (profit-sharing) contracts are profit-sharing agreements in which a bank provides the entire capital needed to finance a project, and the customer provides the expertise, management and labour. The profits from the project are shared by both parties on a pre-agreed (fixed ratio) basis, but in the cases of losses, the total loss is borne by the bank (Chong \& Liu, 2009). Example: You supply funds to the bank after agreeing on the terms of the Mudarabah arrangement then the bank invests funds in assets or in projects, this kind of business may make profit or incur loss. The profit is shared between you and your bank based on a preagreed ratio. Any loss will be borne by you. This will reduce the value of the assets/ investments.

b) Mushaarakah (Regular Partnership or Joint Venture or Profit Loss Sharing (PLS)) under this instrument all involved parties participate as partners in a business or a trade. They share losses together and profits together. Each partner takes his share of the profit/loss in proportion to his initial investment in the business and agreed upon terms and conditions (Muzaffar, Gerard, \& AI-Elaiwi, 2000). The joint venture is an independent legal entity, and the bank may terminate the joint venture gradually after a certain period or upon the fulfillment of a certain condition (Chong \& Liu, 2009). Example: The bank enters into an equity partnership agreement with one or more partners to jointly finance an investment project. Profits (and losses) are shared strictly in relation to the respective capital contributions (Grais \& Pellegrini, 2006). 
2. Non Participatory modes: Main forms of non-participatory (non-profit and loss sharing, or trade based) Islamic finance is:

a) Murabaha financing is based on a mark-up (or cost plus) principle, in which a bank is authorized to buy goods for a customer and resell them to the customer at a predetermined price that includes the original cost plus a negotiated profit margin9. This contract is typically used in working capital and trade financing (Chong \& Liu, 2009). Example: A firm in need of upgrading its existing machinery would approach an Islamic Bank to obtain the machinery on its behalf, with a concomitant agreement to purchase the machinery on a marked-up basis from the bank. If the bank's purchase price was $\$ 100,000$, it might resell the machinery to the firm for, say, $\$ 110,000$ payable in 12 equal monthly installments. The bank retains ownership until the last installment is paid and so the bank's position is fully secured. This is accepted as Shariah -compliant by most authorities (Khan, 2010).

b) Musawama: Normal market sale with no cost disclosure obligation (Khan, 2010).

c) Al-Ijarah financing is similar to leasing (Chong \& Liu, 2009). This is the Shariah's concept of leasing finance whereby the bank purchases the asset required by the customer and then leases the asset to the customer for a given period, the lease rental and other terms and conditions having been agreed on by both parties (Haron, Ahmad, \& Planisek, 1994). Example: A bank buys an asset for a customer and then leases it to the customer for a certain period at a fixed rental charge. Shariah (Islamic law) permits rental charges on property services, on the precondition that the lessor (bank) retain the risk of asset ownership (Chong \& Liu, 2009).

d) Istisna'a - is a contract under which a bank is financing the working capital of a company. Here are included especially those goods that cannot be financed by leasing (Botiș, 2013). It can be used in the financing of manufactured goods, construction and infrastructure projects (Chong \& Liu, 2009).

3. Sub Contracts

a) Sukuk - are bonds, issued by a bank for the financing of a specific mediumor long-term project, which can be implemented by both public and private companies (Botiș, 2013).

b) Wakalah (Agency): It means a contract whereby a person (principal) asks another one to act on his behalf (as his agent) for a specific task. The agent will be paid a fee for his services (Botiș, 2013). Example: A customer asks a bank someone under certain terms. The bank is therefore the agent for carrying out the financial transaction and the bank will be paid a fee for its services (Baber, 2013).

c) Qardul Hassana (Interest-Free Loan) In Islam, Qardul Hassana, is literally translated as Good Loan, but practically it means interest-free loan to an individual or an institution in need. In the context of the Holy Quran, the fact that a person is blessed with more wealth than what he needs or than others have is a blessing from Allah Almighty. Such a person should be thankful to God for this bounty and the best way to fulfill thanks is to make his extra wealth available for other needy mem- 
bers of the society. These needy members may be in temporary need in the form of a loan, which can be returned at the agreed upon future date without interest. If a person is determined a priori that he will not be in a position to return the money, the money can be given to him as obligatory or voluntary charity.

d) Juala: Service charge, consultancy fee, placement fee, etc. A party pays another a specified amount of money as a fee for rendering a specific service in accordance to the terms of the contract stipulated between the two parties. This mode usually applies to transactions such as consultations and professional services, fund placements and trust services (Grais \& Pellegrini, 2006).

\section{Conclusions}

The purpose of the current study is to shed the lights of the Islamic Banking System and compare between it with the Conventional Banking System. The results showed the following:

1. Islamic banks numbers has been increasing in Islamic nations and in other countries all over the world. Along with purely Islamic banks, conventional banks are also in this race to target the mass with Islamic banking needs.

2. Recently, the performance of Islamic bank is remarkable. That means there are many economical pros in using Islamic banking.

3. The most obvious finding to emerge from this study is the emergence of Islamic banking as an alternative for conventional banking systems.

4. The switch to Islamic banking will be a difficult task. There are many obstacles will face this process and the changeover will not be an 'overnight' process by any means. Although the switch in Muslims nations is easier especially after the economic crises. Major Banks wish to cash in on this desire but cannot provide truly Sharia-compliant vehicles.Therefore they look for scholars willing to certify de facto conventional instruments as Sharia-compliant.

\section{Literature}

Abdul-Majid, M., Saal, D.S., \& Battisti, G. (2010). Efficiency in Islamic and conventional banking: an international comparison. Journal of Productivity Analysis 34, no. 1, pp. 25-43.

Ahmad, A.F., \& Hassan, M.K. (2007). Riba and Islamic banking. Journal of Islamic Economics, Banking and Finance, 3(1), pp. 1-33.

Ahmad, I., \& Shabbir, G. (2003). Frequently Asked Questions (FAQs) on Islamic Banking. Retrieved 11 25, 2011 , from State Bank of Pakistan: www.sbp.org.pk/departments/ibd/faqs.pdf

Alam, M.N. (2003). Islamic Banks(A Comparative Study Between Islamic and Conventional Banking Systems). Retrieved 11 10, 2011, from Islamic Business Research Center: www.kantakji.com

(n.d.). Al-Baqara. In Qur'an Kareem (pp. 275-276).

Al-Sader, S.M. (1994). The Non-Usury Bank in Islam. Beirut: Dar Al-Taarof For Publications. 
Baber, H. (2013). Islamic Banking in Indian Economy-An Empirical Approach of Future Crisis. International Monthly Refereed Journal of Research In Management \& Technology Vol. II, pp. 34-47.

Botiș, S. (2013). Shari'ah Concepts in Islamic Banking. Bulletin of the Transilvania University of Brasov. Series V: Economic Sciences 6, no. 2, pp. 139-146.

Chong, B.S., \& Liu, M.-H. (2009). Islamic banking: Interest-free or interest-based? Pacific-Basin Finance Journal 17, pp. 125-144.

Choudhury, M. (1986). Contribution to Islamic economic theory. Hong Kong: The Macmillan press Ltd.

Dar, H., \& Presely, R. (2000). Lack of profit loss sharing in Islamic banking: management and control imbalances. Department of Economics, Loughborough University.

El Diwany, T. (2010). The Problem With Interest. Kreatoc Ltd.

Elasrag, H. (2014, May 26). Corporate governance in Islamic Finance: Basic concepts and issues. Retrieved August 15, 2014, from Munich Personal RePEc Archive: www.mpra.ub.uni-muenchen.de/56872/

Gambling, T., \& Karim, R. (1991). Business and accounting ethics in Islam. London: Mansell Publishing Limited.

Grais, W., \& Pellegrini, M. (2006). Corporate governance in institutions offering Islamic financial services: issues and options. Vol. 4052. World Bank Publications.

(n.d.). Hadith Muslim. Prophet Mohammed.

Haron, S., Ahmad, N., \& Planisek, S.L. (1994). Bank Patronage Factors of Muslim and Non-Muslim Customers. International Journal of Bank Marketing 12, no. 1, pp. 32-40.

Hind, D. (2007). The threat to reason: how the enlightenment was hijacked and how we can reclaim it. VERSO, London.

Husain, I. (2005). Islamic financial services industry: the European challenges. Keynote address at the Islamic financial services forum. Luxembourg: Islamic Financial Services Board and Central Bank of Luxembourg.

Iqbal, M., \& Molyneux, P. (2005). Thirty Years of Islamic Banking: History, Performance, and Prospects. Islamic Econ., Vol. 19, No. 1, pp. 37-39.

Kahf, M. (2002). Strategic trends in the Islamic banking and finance movement. The Fifth Annual Forum of Harvard Program on Islamic Finance and Banking (pp. 1-31). Cambridge: Harvard University Press.

Kahf, M. (2004, January). Success Factors of Islamic Banks. Brunei: Brunei Symposium on Islamic Banking and Finance.

Kamali, M.H. (2003). Principles of Islamic jurisprudence. Cambridge: Islamic Texts Society.

Kamla, R. (2009). Critical Perspectives on Accounting. Elsevier, pp. 921-932.

Khan, F. (2010). How 'Islamic' is Islamic Banking? Journal of Economic Behavior \& Organization, pp. 805-820.

Malaysia, C.B. (1999). The central bank and the financial system in Malaysia: a decade of change 1989-1999. Bank Negara Malaysia: Kuala Lumpur.

Muzaffar, A.S., Gerard, A.C., \& AI-Elaiwi, A.H. (2000). Globalization, Technology, and Interest-Free Islamic Banking. IEEE, pp. 245-248.

Rad, S.T. (June 2006). Legal and regulatory environments for Islamic finance.Events Reviewed. The Middle East in London.

Sadoveanu, D. (2011). Islamic Banking In European Union Countries: Challenges And Opportunities. CES Working Papers 4 (2011), pp. 592-598.

Wilson, R. (2007). Islamic investment in the UK. Business Islamica, pp. 68-72.

Wilson, R., \& Hind, D. (1997, 2007). Economics, ethics and religion, The threat to reason: how the enlightenment was hijacked and how we can reclaim it. London: Macmilan Press Ltd., VERSO. 


\section{ISLAMSKI SYSTEM BANKOWY JAKO EFEKTYWNY ELEMENT GOSPODARKI}

Streszczenie: Głównym celem artykułu jest prezentacja instrumentów bankowości islamskiej (rodzaju bankowości zarządzanej przy wykorzystaniu praw religijnych islamu, któremu podporządkowane jest życie muzułmanów - Shariah) oraz odpowiedź na pytanie, dlaczego odgrywają one tak ważną rolę w społeczeństwie. Zgodnie z regułami Shariah nie ma możliwości akceptacji stóp procentowych nawet w przypadku transakcji bankowych. W tym artykule zamieszczono główne cechy charakterystyczne transakcji bankowych w systemie finansów islamskich oraz wskazano różnice między bankowością islamską a tradycyjną. Dodatkowo zamieszczono rys historyczny prezentujący ewolucję tego systemu bankowego w krajach muzułmańskich, zaczynając od otwarcia banku Nassera w Egipcie w 1960 roku. Gwałtowny rozwój bankowości podporządkowanej zasadom islamu w ostatniej dekadzie wymusił na tradycyjnych bankach adaptację tego typu instrumentów i dostosowywanie oferty banków uwzględniających tę okoliczność nie tylko w krajach muzułmańskich.

Slowa kluczowe: bankowość islamska, finanse islamskie, lichwa, instrumenty islamskie 